\section{A Little-known Peculiarity of the Hamadryad Snake.}

A structural peculiarity of the "king cobra" which I have recently ascertained while studying the anatomy of the Ophidia seems to me to be so remarkable that it must have been noticed in such comprehensive works as Bronn's "Thierreich" and Dr. Gadow's account of serpents in the " Cambridge Natural History" were it known. I venture, therefore, to give a short account of the matter without professing to have made an exhaustive survey of the literature of the group. The windpipe of this snake opens, as usual, not far from the heart into the lung, which presents no remarkable divergencies from the lungs of other snakes ; it is in the same way functional as a lung for the first half, and becomes a mere thin-walled air bag posteriorly. Before opening into the lung, however, the trachea is connected with a long series of approximately equi-sized air sacs in the neck, which follow close upon each other, and entirely occupy the neck down to the region where the heart lies. These sacs are so closely adpressed that the appearance given is that of a series of septa, dividing the space surrounding the windpipe and gullet into metamerically arranged compartments. I thought at first, in fact, that I had been able to observe a segmentation of the cœlom in this region quite analogous to that of an annelid. Each cavity, however, is continuous with the interior of the windpipe by an oval and clearly defined orifice on its lower surface. These apertures are regular and of fairly equal size, and give to the windpipe quite the appearance of a flute. There are a large number of them, thirty to forty. There is no question here of pathological conditions or of accidental cuts. The regularly disposed series of sacs into which they open negatives anything of the kind. They are, I suppose, an extreme modification of what the late Prof. Cope termed the "tracheal lung" in Chersydrus and other snakes. The most obviously comparable structure that I can think of for the moment is the ventral slit in the windpipe of the emu, which similarly opens into a thin-walled sac. This is believed to be connected with the singular "drumming" sound emitted by that bird. Perhaps some of your readers who are acquainted with the Hamadryad can inform me as to a possible "voice," or whether it can produce a varied or especially prolonged hiss. I propose to offer a more detailed account of the structure of the windpipe and other organs of this snake to the Zoological Society as soon as possible.

Frank E. BEDDARD.

\section{The New Bishop's Ring}

Regarding M. Forel's suggestion (see Nature, p. 396) that persons ascending to considerable altitudes should observe whether the ring around the sun, which was so noticeable a phenomenon after the diffusion of the volcanic dust from the Krakatoa eruption in 1883 , is again visible, I beg to say that, before reading his letter in La Gazette de Lausanne, I had noted the ring on August 20 from the Montanvert, near Chamonix, at an altitude of 6300 feet. The day was exceptionally clear, and when a peak hid the sun itself, the whitish glare fringed with reddish brown that surrounded it attracted my attention. Being upon the summit of Mont Blanc (15,780 feet) on September 1 , in clear weather, I again observed the ring, which, however, was no better defined than lower down on the mountain, notwithstanding the circumstance that the dark blue sky furnished an excellent background. Angular measurements there showed that the radius of the visible outer limit of the reddish ring was between $20^{\circ}$ and $25^{\circ}$.

While the phenomenon was not again seen by me last summer in Europe, it has. often been observed during the past year here at my observatory, elevated only 6.40 feet above the sea, and an article in Science of January 23 by my assistant, Mr. Clayton, describes the reappearance of this second "Bishop's ring" and the accompanying brilliant sunsets during the early part of last winter. Subsequently, the ring was observed in January and February, and also in May, June, and July, when highly coloured and prolonged afterglows followed the sunsets towards the close of the latter month. During the first part of August the ring was seen on clear days, and during September the vivid yellow colour of the western sky, persisting sometimes more than an hour after sunset, was frequently recorded. To-day (October 14), after a period of rainy No. 1774 , voL. 68$]$ weather, the ring is distinct, and measurements made here some time ago gave $26^{\circ}$ as the radius of the whitish haze and $5^{\circ}$ more for the reddish border, indicating that its visible extension was greater even than on Mont Blanc.

M. Forel states that he has seen a coloured circle surrounding the sun since the first of last August. The fact of it not having attracted notice previously in Europe would seem to show either that the clearer atmosphere of the United States favours its perception, or that the microscopic dust in the upper air, which is supposed to produce the diffraction phenomenon, preponderates above this country. The last hypothesis is supported by the fact that, from the proximity of the West Indian volcanoes, the fine dust ejected by them during the eruptions that year may have drifted northward, before making a circuit of the globe, and a larger quantity may still remain suspended in the rarefied atmosphere above the eastern United States than exists over Europe. A. LAWRENCE Rotch.

Blue Hill Meteorological Observatory, Massachusetts,

$$
\text { U.S.A., October 14. }
$$

\section{The Nervous System of Anodonta cygnea.}

THE supra-œsophageal ganglion of Anodonta is usually regarded as representing both the cerebral and pleural ganglia, and is commonly spoken of as the "cerebropleural." Prof. Howes mentions in his "Atlas " that Prof. M. Hartog has occasionally observed a ganglionic swelling on one or both of the cerebro-visceral connectives in fron of the pericardium, but that he himself has failed to find any such enlargement. In view of the doubt that exists, it seems to be worth recording that yesterday one of my pupils, A. C. Roxburgh, while dissecting an Anodonta in the Charterhouse laboratory, exposed a well-developed ganglion of the usual orange colour, upon the left connective in the exact position mentioned by Prof. Hartog. Microscopical examination removed all doubt as to the nature of the swelling. for numerous ganglion-cells were easily recognised in the teased preparation. It is thus probably more correct to term the anterior ganglion "cerebral" rather than cerebro-pleural. Perhaps some of those who are better equipped for research than is possible or advisable for those engaged in elementary laboratories might find it worth while to examine series of sections of the connective at this region. It is possible that the pleural ganglion may in most cases be represented by but a few ganglion cells the presence of which is not discernible to the unaided eye.

May I, as I am writing about this animal, direct attention to an error that is universal in text-books? The muscles always spoken of as retractors and protractor of the foot have not the function that their titles imply. The protrusion of the foot is due to vascular turgescence, and its withdrawal to relief of the turgid condition and contraction of the intrinsic pedal muscle fibres. The muscles in question move the shell, the foot being the fixed point. Thus the so-called anterior and posterior retractors of the foot should be styled the protractors of the shell, and the protractor of the foot the retractor of the shell. I may mention that I have often seen Anodonta go backwards when its deliberate movements have led it into a cul-de-sac in the aquarium.

Charterhouse, Godalming, October 24.

\section{LORD KELVIN AND HIS FIRST TEACHER IN NATURAL PHILOSOPHY.}

SOME interesting early recollections were related by Lord Kelvin on October 17 , on the occasion of the unveiling of a stained glass window, by Henry Holiday, in the Bute Hall of the University of Glasgow in memory of John Pringle Nichol, LL.D., professor of astronomy, $1836-1859$, and his son and daughter, John Nichol, LL.D., professor of English language and literature, 1862-1889, and Mrs. Jack, who was born in 1837 , in the University, and died there in rgor. Prof. J. P. Nichol was the author of numerous valuable works, including the famous book on the "Architecture of the Heavens." The account which Lord Kelvin gave of his own young days at 